The Relationship Between Self-Congruity, Brand Relationship Quality, and Brand Loyalty

Lystia Hapsari

Independent Fashion Analyst in Surabaya

hapsari_listya@yahoo.com

Mobile Phone: +62.817252868

Michael Adiwijaya

Lecturer, Faculty of Economics

Petra Christian University, Surabaya - Indonesia.

michaels@petra.ac.id

Mobile Phone: +62.81331660100 


\title{
The Relationship Between Self-Congruity, Brand Relationship Quality, and Brand Loyalty
}

\begin{abstract}
The rapid growth of fashion industry in Indonesia has created intense competition among the fashion industry players and attracted many international brands to expand to Surabaya as the second big city in Indonesia. The upper middle class customers in Surabaya express their status by projecting the brand image of the product that they buy and wear. This phenomenon creates the strong relationship between the customer and the brand that contributes to the development of brand loyalty. MANGO is one of the international brands that is targeting the upper middle class customers in Surabaya. This research will reveal the influence of customer self congruity towards brand relationship quality and brand loyalty for MANGO products. The structural equation modelling is used to measure and to analyze the research variables. The findings show that customer self congruity positively influences brand loyalty; while the customer self congruity negatively influences brand relationship quality; and finally brand relationship quality negatively influences brand loyalty.
\end{abstract}

\section{Keywords :}

Self Congruity, Brand Relationship Quality, Brand Loyalty

\section{INTRODUCTION}

The image of a particular product or service contributes to the status, image, and social roles for certain customer segments where those customer expressed their status through their lifestyle and through the products or services that they consumed (Parker, 2005). Diamond \& Gerald (2008) argued that product labeling is the key factor for customer purchase behavior. Customers use product labeling to identify the certain social class and groups. Therefore, in many cases, the customers often buy the secondary (acquired) need product instead of the primary one.

According to Schiffman and Kanuk (2000), the acquired need is a learned need that is originated from the culture response and the surrounding environment or what we called as psychological need. The driver of human need is human motivation. In this case, it is the emotional motives that play important role to drive the customers to make a decision to buy a product not only for gaining the functional benefit but also for gaining the emotional benefits; for instance the prestige and the status (Diamond and Gerald, 2008). Customers often use product brand to show who they are among the others. Keller (2008) stated that the customers will choose and consume the brand which has the personality that is congruent and consistent with their self concept. Kresmann et al (2006) mentioned the term for this phenomenon as self image congruence. Self- image congruence refers to the match between consumers' self-concept and the user image of a given product, brand, store.

The Indonesian consumer behavior research that was conducted by Rahardja (2011) revealed 10 unique consumer behavior characteristics such as short thinking, impulse buying, collectivism, technology illiterate, context orientation, foreign brands minded, religious, high self esteem, influenced by sub culture, and environmentally unfriendly (cited on Frontier, 2007). Based on the research finding, we found foreign brands minded and high self esteem that are reflecting the Indonesian consumer behavior which concern to brand image when it comes to purchase decision.

A brand of product has its personality that reflects the image of the costumer who is using it. Therefore, the brand image could influence the customer image (Kressmann et al, 2006). As the consequence, the customers are trying to evaluate and to create congruence between their self concept towards the image of the brand that they consume; this process is called self congruity (Sirgy, 1986). According to Maholtra (1988), this process significantly influences shopping motivation and brand loyalty. Customers develop strong relationship towards the brand which customers believe and expect could enhance their self image. The strong and intimate relationship between the customers and the brand is known as brand relationship quality (Kressmann et al, 2006). When a customer admires the brand that is able to enhance his/her self image then it will create brand 
loyalty (Durianto et al, 2001). Every luxury brand has its own unique value and image that is expected to be delivered to its target market. Nowadays, the customer is becoming more critical and demanding to explore about the unique values of the brand as well as the brand image that could contribute to his/her self image. A luxury brand is supposed to deliver the experience as what customer expect as well as deliver the image as what customer would like to be displayed (Ibrahim, 2006).

One of luxury brands that can be found in Surabaya, the second largest city in Indonesia, is MANGO. This is an international brand which is well known for its design, manufacturing process, and market for fashion and accessories products for both men and women. MANGO applied the concept of fast fashion (Wall Street Journal, 2004) which is the retail concept that directs the business strategy to reduce the time for stocking the inventory and to conduct in season buying system that ensures the store in offering the latest mode throughout the season (Barnes and Greenwood, 2010). MANGO tends to target the customer on the age range from 18 to 35 years old with the demographic characteristics that are similar to other brands such as GAP, Banana Republic, and Abercombie \& Fitch (Moin, 2006). The customers on the age range from 20 to 34 years old are willing to spend more on fashion product compared to the customers on the age below 20 years old. Meanwhile for customer, who is on the age above 35 years old, tends to purchase the luxurious brands (Hawkins et al, 2004). The purpose of this research is to identify and to analyze the influence of self congruity towards the brand relationship quality and brand loyalty. MANGO is chosen as the case study to explore the consumer behavior in Surabaya, Indonesia.

\section{LITERATURE REVIEW Self-Concept}

Parker (2005) stated that the foundation of self image or self concept is the way an individual perceived about him/herself. An individual has no self concept when he/she was born but this concept will grow as the individual deals with others in his/her society. According to Hanna and Wozniak (2001, p. 272) self-concept is the overall picture of an individual; it is about what he/she believes and feels about him/herself. Self concept also emerges out of other people's opinion of us and we learn to perceive ourselves as others perceive us. There are several components of self concept as follow (Koter, 2000, p17): Actual self-concept which refers to the way of an individual perceived about him/herself; Ideal self-concept which refers to the way of an individual would like (expect) other people to perceive about him/herself; Other self-concept which refers to the way of an individual perceived about the way other people perceived about him/herself.

An individual will protect and transform his/her self concept when dealing with others' behavior and lifestyle in reference to group interaction (Blackwell et al., 2001, p.399). The customers tend to pick the product or brand as well as shop at the store that has similar image with their self image. This process of matching the image is known as self congruity (Parker, 2005). Self congruity is the relationship between customer self concept and the image of a product brand or store brand (Sirgy, 2007). Next, Hanna and Wozniak (2001, p.274) argued that self congruity is the tendency of an individual (customer) to buy a product that is congruence with some aspect of him/herself.

\section{Brand Relationship Quality}

Fournier (1998) defines consumer brand relationship as human interpersonal relation under four conditions as follow: firstly, relationship involves the interaction of two parties; secondly, relationship is something that is deliberated; thirdly, relationship is something complicated with many forms; and finally relationship is always changing and growing. Brand relationship quality is the strong intimate relationship between the customer and the brand (Kressmann et al., 2006). Actions of the brand toward the consumer play an important role in how a consumer evaluates his or her relationship with the brand (Monga,2002). Based on Keller (2008, p.388), there are 6 main dimensions on brand relationship quality. They are interdependence, self concept, commitment, love / passion, intimacy, and partner quality. In addition, Kressmann et al (2006) explained that the source of motivation underlying brand relationship quality is social attachment. The more a brand contributes to his/her image perceived by others, the stronger emotional bind between the customer and the brand. 


\section{Brand Loyalty}

Loyalty is a behavior where customers decide to be or not to be a loyal customer; meanwhile, brand loyalty is defined as the proportion of consumer time to purchase the same brand under the specific product category compared to the other brand under the same product category (Neal, 2008, p.146). Brand loyalty is a consumer's consistent purchase of a specific brand within a given product category over time (Hanna \& Wozniak, 2001, p.157). Another opinion by Peter and Olson (2005) regards brand loyalty as the fundamental commitment in repeating the purchase of special brand. Brand loyalty is the measure of customer involvement towards a brand (Durianto et al, 2001). There are two approaches to measure brand loyalty (Chahal \& Bala, 2010); the attitudinal brand loyalty and behavioral brand loyalty. The attitudinal brand loyalty refers to consumer intention to conduct repeat purchases toward a certain brand in the future as well as recommending the brand to others. While the behavioral brand loyalty refers to the activity to conduct repeat purchases toward a brand in a specific period of time and the consumer tendency to spent most of his/her revenue to purchase a certain brand. In addition the selected brand dominates the consumer product collections.

\section{The Relationship Between Self Congruity, Brand Relationship Quality, and Brand Loyalty}

Self concept is one of the important things that is influencing consumer decision on a certain brand. The consumer tends to purchase brands which have similar image to his/her self image. (Blackwell et al, 2001, p.399). This phenomenon will create a strong and intimate relationship between the consumer and the brand. This relationship refers to brand relationship quality (Kressman et all, 2006). Therefore a customer who found the brand image is congruent with his/her self image will develop and maintain the relationship with selected brand. It means that the stronger self congruity will increase the brand relationship quality and vice versa. Thus hypothesis 1 can be formulated as follow:

H1: There is a positive influence from self congruity towards brand relationship quality

A customer who has a strong brand relationship quality refers to the satisfied customer towards brand performances. Ruyter and Bloomer (2010) argued that customer satisfaction will lead to customer loyalty. Moreover, Durianto et al (2001) stated that commonly a customer who has positive brand relationship quality will show committed behavior toward a certain brand. It means that the stronger brand relationship quality will increase brand loyalty. Therefore hypothesis 2 can be formulated as follow:

$\mathrm{H} 2$ : There is a positive influence from brand relationship quality towards brand loyalty

Kressmann et al (2006) stated that customer self congruity is one of the key factors on consumer decision making process. Moreover, Ibrahim and Najjar (2008) argued that consumer purchase decision towards a brand is also influenced by social norms. These norms will create customer pride when using certain brands that are accepted and admired by the certain social group. It means that if self congruity is increasing then it will increase brand loyalty. Therefore hypothesis 3 can be formulated as follow:

H3: There is a positive influence from brand relationship quality towards brand loyalty

\section{METHODOLOGY}

The quantitative research approach has been done for this research by using the type of correlational research. According to Noor (2011), correlational research is the study to identify the relationship between two variables or more; in this research, the variables are self congruity, brand relationship quality, and brand loyalty. The population for this research is MANGO customers who live in Surabaya, Indonesia. The sample criteria are 
women from 18 to 35 years old, live in Surabaya, and have bought more than 3 MANGO products within a year.

The total sample size is 100 respondents which is taken by using non probability random sampling approach through purposive sampling technique. This technique refers to the sample determination based on certain considerations. In this case based on sample criteria (Martono, 2010, p.70). The data is collected by using questionnaire through store intercept survey which is distributed to MANGO customers.

There are four sections within the questionnaire. The first section is respondent screening; in this section researcher eliminates unqualified respondents who do not meet the sample criteria. Then the second section is respondent profile; in this section researcher measure the respondent lifestyle by using AIO (Activities, Interests, Opinion) Approach. Moreover the third section is shopping behavior; in this section researcher measures the shopping behavior of respondent such as amount of spending, time spent, shopping priority, etc. Finally, the fourth section is about the main research variables; in this section the researcher measures respondent's self congruity, brand relationship quality, and brand loyalty. The instruments of questionnaire was measured using likert scale from strongly disagree (1) to strongly agree (5). Then Structural Equation Modeling (SEM) technique is used to measure and to analyze the research variables. This analysis technique consists of two analysis; the factor analysis and the path analysis.

The research framework can be seen on figure 1. below:

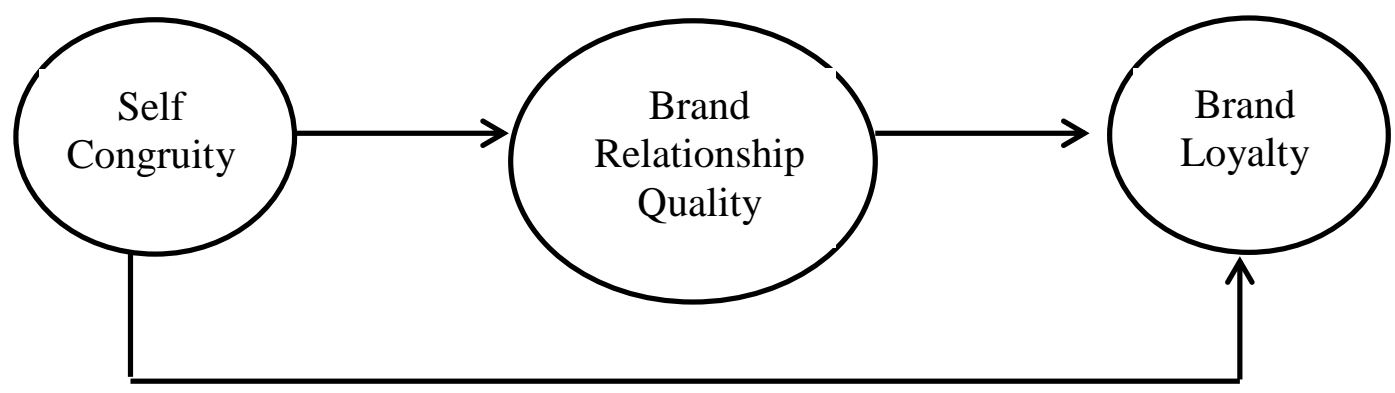

Figure 1: Research Conceptual Framework

\section{FINDINGS}

\section{Sample Characteristics}

Of the respondents, $(40 \%)$ on the age range of $18-22$ years old; $(35.2 \%)$ on $23-29$ years old, and $(24.8 \%)$ on $30-35$ years old. The frequency of shopping transaction for MANGO products within a year is $(45.7 \%)$ for 3 to 5 times and $(54.3 \%)$ for more than 5 times a year. Next, monthly disposal income is (32.4\%) on the range of Rp $2-3.5$ millions; (21.9\%) on the range of Rp $3.6-5$ millions; and (36.2\%) above Rp 5 millions. The lifestyle of the respondents is as follow; (70.5\%) respondents prefer outdoor activities and only (29.5\%) prefers indoor activities. Moreover for opinions; $(75.2 \%)$ respondents argue that male customers are supposed to follow fashion trends and only $(24.8 \%)$ disagree with that opinion. Next, $(74.3 \%)$ respondents are searching for entertainment while shopping and only $(25.7 \%)$ disagree with that opinion. Regarding the respondents interest on the priority of life; the top priority is family while the second one is achievement, the third is friends, the fourth is work, and the last is hobby. Regarding the shopping behavior of respondents; the priority in purchasing luxury brand product is; (42\%) the product comfort; $(25 \%)$ self confident when using the brand; and (17\%) fashion trends. The average spending per transaction is $(36.2 \%)$ from $\operatorname{Rp~} 410.000,-$ to $\operatorname{Rp} 600.000,-;(38.1 \%)$ 
from $\mathrm{Rp} 610.000,-$ to $\mathrm{Rp} 800.000,-$; and (12.4\%) above Rp 800.000,-. Respondents who spent less than 30 minutes in a fashion store is $(30.5 \%) ; 30-45$ minutes is $(43.8 \%)$; and $45-60$ minutes is $(25.7 \%)$.

\section{Consumer Behavior}

The consumer behavior of respondent that comprises of three variables; self congruity, brand relationship quality, dan brand loyalty is measured by mean score. The mean score above 3.5 indicates the level of approval. The mean score for all research variables can be seen on table 1.1 below:

Table 1. Mean Score Research Variables

\begin{tabular}{|l|l|}
\hline Self-Congruity & Mean \\
\hline Actual Congruity & 3,60 \\
\hline Ideal Congruity & 3,50 \\
\hline Social Congruity & 3,75 \\
\hline Total & 3,67 \\
\hline Brand Relationship Quality & Mean \\
\hline Interdependent & 3,47 \\
\hline Self-concept connection & 4,11 \\
\hline Commitment & 3,63 \\
\hline Passion & 3,05 \\
\hline Intimacy & 3,46 \\
\hline Partner Quality & 3,21 \\
\hline Total & 3.48 \\
\hline Brand Loyalty & Mean \\
\hline Purchase intention & 3,48 \\
\hline Recommendation & 3,49 \\
\hline Repeat purchase & 3,51 \\
\hline Special budget & 3,47 \\
\hline Majority collection & 3,70 \\
\hline Total & 3.53 \\
\hline
\end{tabular}

From the table 1; it can be seen that the total mean score for self congruity variable is (3.67) which means that the image of MANGO is congruent with self image of the respondents. While the mean score for each indicator is; actual congruity (3.60), ideal congruity (3.50), and social congruity (3.75). This also indicates the congruence with MANGO brand image. The mean score for self congruity variable along with its indicators can be interpreted that the level of congruence is on the middle level by considering the highest score is at (5.00). Next, for brand relationship quality variable, the total mean score is (3.48) which means that the respondents do not have a strong and intimate relationship with MANGO brand. While the mean score for each indicator is; interdependent (3.47), self concept connection (4.11), commitment (3.63), passion (3.05), intimacy (3.46), and partner quality (3.21). The scores indicate that all indicators do not support good quality of brand relationship level except for commitment indicator. The mean score for brand relationship quality variable along with its indicators 
can be interpreted that the level of intimacy is on the middle level by considering the highest score is at (5.00).

Moreover for brand loyalty variable, the total mean score is (3.53) which means that respondents are loyal to MANGO brand. While the mean score for each indicator is; purchase intention (3.48), recommendation (3.49), repeat purchase (3.51), special budget (3.47), and majority collection (3.70). The scores indicate that all indicators do not support good loyalty level except for repeat purchase and majority collection. The mean score for brand loyalty variable along with its indicators can be interpreted that the level of loyalty is on the middle level by considering the highest score is at (5.00).

\section{Hypothesis Testing}

Structural Equation Model is used to analyze the data. Figure 1.2 displayed the path diagram for data analysis for the research model.

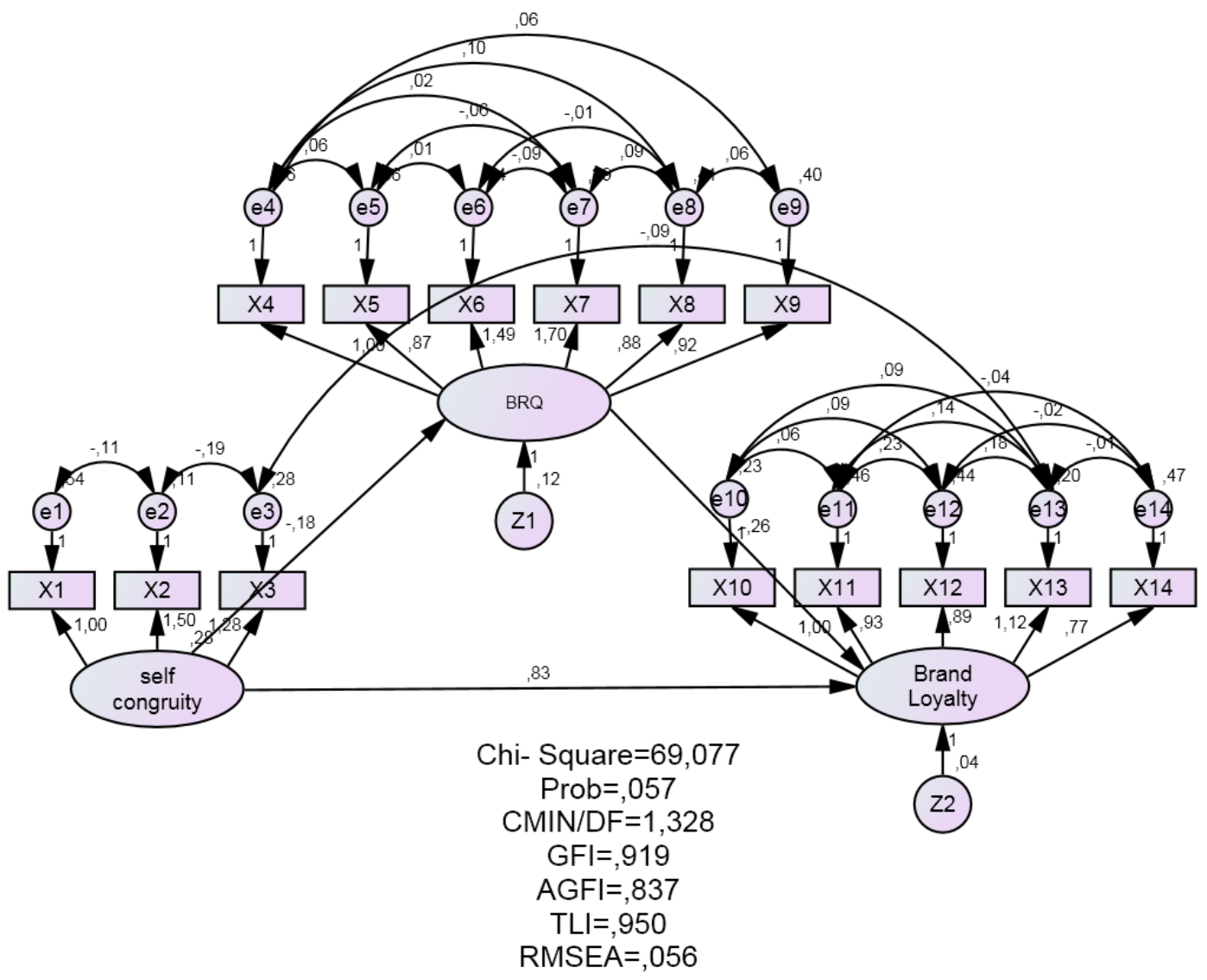

Figure 2: Path Diagram

From figure 2; it can be seen that the entire indicators are the predictor of the variables. Self congruity variables are developed by three indicators; they are actual congruity (X1), ideal congruity (X2), and social congruity (X3). While brand relationship quality is developed by six indicators; interdependence (X4), self concept connection (X5), commitment (X6), passion (X7), intimacy (X8), and partner quality (X9). Finally, brand loyalty is developed by five indicators; purchase intention (X10), recommendation (X11), repeat purchase (X12), special budget (X13), and majority collection (X14). The score of Chi Square, Probability, CMIN/DF (The Minimum Sample Discrepancy Function), GFI (Goodness of Fit Index), AGFI (Adjusted Goodness of Fit) RMSEA (The Root Mean Square Error of Approximation) and TLI (Tucker Lewis Index) are used to measure the overall fit of research model. This research model is fit and can be used as the model for research analysis 
based on these scores: Chi Square score is (69.07) and Probability score is (0.057); both score lower than significancy level (0.005); CMIN/DF score is (1.328) which is lower than cut off value score (2.0); GFI score is (0.919) which is higher than cut off value score (0.900); AGFI score is (0.837) which is higher than cut off value (0.800); RMSEA score is (0.056) which is lower than cut off value score (0.08); and finally TLI score is (0.950) which is higher than (0.90).

The result for hypothesis testing can be seen from table 2 and table 3 below:

\begin{tabular}{|c|c|c|c|c|c|c|}
\hline & & Estimate & S.E. & C.R. & $\mathbf{P}$ & Label \\
\hline BRQ & <---Self_congruity &,- 175 & ,093 & $-1,877$ & ,061 & par_13 \\
\hline $\begin{array}{l}\text { Brand_- } \\
\text { Loyalty }\end{array}$ & $<---$ Self_congruity &, 834 & 191 & 4,354 & $* * *$ & par_12 \\
\hline $\begin{array}{l}\text { Brand__ } \\
\text { Loyalty }\end{array}$ & <--- BRQ &,- 260 &, 154 & $-1,691$ & ,091 & par_14 \\
\hline
\end{tabular}

Table 2: Reggression Weight

\begin{tabular}{|c|c|}
\hline & Estimate \\
\hline BRQ <--- self_congruity &,- 253 \\
\hline Brand_Loyalty <--- self_congruity & 853 \\
\hline Brand_Loyalty <--- BRQ &,- 185 \\
\hline
\end{tabular}

Table 3: Standardized Regression Weights

For hypothesis 1:

H1: There is a positive influence from self congruity towards brand relationship quality

From table 2; it can be seen that the probability score is not significant $(0.61)$ which means that self congruity does not significantly influence brand relationship quality and therefore hypothesis 1 is rejected.

For hypothesis 2:

$\mathrm{H} 2$ : There is a positive influence from brand relationship quality towards brand loyalty

From table 2; it can be seen that the probability score is not significant (0.91) which means that brand relationship quality does not significantly influence brand loyalty and therefore hypothesis 2 is rejected.

For hypothesis 3:

H3: There is a positive influence from self congruity towards brand loyalty

From table 2; it can be seen that the probability score is significant which means that self congruity significantly influences brand loyalty with the estimated score of influence is $(0.853)$ which can be seen from table 3 ; therefore hypothesis 3 is accepted. 


\section{CONCLUSION}

There are several conclusions that can be derived from the research findings. The first conclusion is about the profile of MANGO customers. The unique characteristics of MANGO customer are on the age range of 18- 35 years old, love outdoor activities, searching for entertainment while shopping, concern about family, spent 30 - 45 minutes on a fashion store, spent Rp 410.000,- to Rp 800.000,- per store visit. The second conclusion is that MANGO brand image is congruent with respondents self image which means that the respondents could express their self image by wearing MANGO products. However, unfortunately, the level of congruity is still on the middle level therefore MANGO brand image is not quite successful in enhancing respondents self image. The third conclusion is that respondents do not have a strong and intimate brand relationship quality with MANGO brand. The level of relationship quality is still on the middle level therefore MANGO brand is not quite successful in creating the intimacy with the respondents. The fourth conclusion is that the respondents are loyal to MANGO brand but unfortunately the level of loyalty is still on the middle level which means MANGO brand is not quite successful in creating strong brand loyalty. Moreover, the fifth conclusion is that self congruity does not influence brand relationship quality for MANGO brand. This phenomenon can be understood by considering that the level of image congruity and the level of brand relationship quality are on the middle level. The sixth conclusion is that brand relationship quality does not influence brand loyalty for MANGO brand. This phenomenon can be understood by considering that the level of brand relationship quality and the level of brand loyalty are on the middle level. Finally, the seventh conclusion is that self congruity significantly influences brand loyalty which means that the image congruity could create customer loyalty.

\section{REFERENCES}

Barnes,Liz \& Lea-Greenwood, Gaynor. (2010). Fast Fashion in the Store Retail Environment, International Journal of Retail and Distribution Management: vol 38. Retrieved March 25, 2012, from ABI/INFORM Global (Proquest) database.

Blackwell, R.D; Miniard, P.W. \& Engel, J.F. (2001). Consumer Behavior (9th edition). USA : Harcourt College Publishers.

Chahal, Hardeep \& Bala, Madhu. (2010). Confirmatory Study on Brand Equity and Brand Loyalty : a Special Look at the Impact of a Attitudinal and Behavioural Loyalty. Journal of Business Perspective: vol 14.Retrieved April, 25, 2012, from ABI/INFORM Global (Proquest) database.

Diamond, Jay \& Pintel, Gerald (2008). Retail Buying (8th edition). NJ: Upper Saddle River.

Durianto, D., Sugiarto \& Sitinjak T. (2001). Strategi Menaklukan Pasar Melalui Riset Ekuitas dan Perilaku Konsumen. Jakarta :Gramedia.

Fournier, Susan M. (1998). Consumers and their Brands: Developing Relationship Theory in Consumer Research. Retrieved April 1,2012, from ABI/ INFORM Global Database.

Keller, K .L. (2008). Building, Measuring and Managing Brand Equity (3rd edition). New Jersey : Prentice Hall.

Kotler, Philip (2005). Marketing Management (the millenium edition). New Jersey : Prentice Hall. 
Kressmann , F.,et al. (2006). Direct and Indirect Effect of Self Image Congruence on Brand Loyalty. Journal Business Research. Retrieved March 5,2012, from ABI/INFORM Global (Proquest) database.

Malhorta, N.K. (1988). Self-concept and Product Choice : an Integrated Perspective. J Econ Psychol;vol 9.

Martono, Nanang (2010). Metode Penelitian Kuantitatif: Analisis Isi dan Analisis Data Sekunder. Jakarta: Rajawali Pers.

Monga, A.B. (2002). Brand as a Relationship Partner : Gender Differences in Perspective. Advance in Consumer Research. Retrieved April 1,2012, from ABI/INFORM Global (Proquest) database.

Neal, William. (2008). Value Creation : the Power of Brand Equity. Ohio : Mason.

Noor, Juliansyah. (2011). Metodelogi Penelitian :Skripsi, Tesis, Disertasi dan Karya Ilmiah. Jakarta: Kencana.

Parker, B.T. (2005). This Brand's for me : Brand Personality and User Imagery Based Self Congruity. Journal Business Research. Retrieved March 23, 2012, from ABI/INFORM Global (Proquest) database.

Peter, J. Paul \& Olson, Jerry C. (2005). Consumer Behavior \& Marketing Strategy (7th edition). USA : Mc Graw Hill.

Premium Luxury Brands : Creating a Cut Above the Rest. (2006, December).RetrievedApril1,2012,http://search.proquest.com/docview/224180207?accountid=45762.

Rahardja, Yudi Rakhmat. (2011,Maret). Character Indonesian Consumer (Frontier, 2007).Paper presented at the meeting of the Retailing in Strata Tittle Mall Concepts,Surabaya.

Schiffman, Leon G \& Kanuk, Leslie Lazar (2000). Consumer Behavior (7th edition). London.

Sirgy, M. J. (1986). Self Congruity : Toward a Theory of Personality and Cybernetiss. New York : Praeger Publishers.

Sirgy, M J., et al. (2007). Effect of Self Congruity with Sponsorship on Brand Loyalty. Journal Business Research. Retrieved March 5,2012, from ABI/INFORM Global (Proquest) database.

\section{IMPLICATIONS FOR BUSINESS MARKETING PRACTICE}

This research paper explained about the consumer behavior for luxury product in this case is for MANGO fashion product in Surabaya as the second largest city in Indonesia. The focus of behavior is on three variables; they are self congruity, brand relationship quality, and brand loyalty. The research findings contribute to the development of knowledge for marketing practitioner especially who engage in retail fashion business as follow:

Global brand does not guarantee the creation of brand loyalty. The findings revealed that MANGO as one of premium international fashion brands, failed in creating high level of brand loyalty in Indonesian market. The findings showed that MANGO customer has middle level of brand loyalty. Several alternatives that the marketer could do to increase the loyalty for instance conducting rebranding programs as well as developing the good quality of relationship with customers. In this case MANGO stays at the comfort zone then it neglects the importance of customer relationship toward its brand. A good brand should develop strong and intimate relationship with its target market to develop high relationship of quality level. Other research findings that were conducted by Kressmann et al (2006) argued that brand relationship quality will influence brand loyalty. In this 
paper findings, MANGO failed to develop strong and intimate relationship. Therefore it is not suprising that MANGO customers show middle level of brand loyalty.

Next, the professional marketer should understand the characteristics of their target market. In this case MANGO failed to cultivate the comprehensive information regarding the characteristics of its customer. Actually MANGO customer perceived that MANGO brand image is congruent with their self image but the level of congruity still on the middle level. In this situation, there is potential for MANGO to enhance the level of customer congurity by developing the brand relationship quality through several innovative programs based on the characteristic of its customers for example the customer demographic profile (income, occupation, etc), customer lifestyle (activity, opinion, and interest), and shopping behavior (time spent, money spent, etc)

In addition the research findings showed that MANGO customer has middle level of brand loyalty. It means that the customer has many other brand options as the shopping alternative and this situation brings the consequences of high level of brand switching. In this case, the marketer should anticipate this situation through market research activities for instance measuring brand loyalty level or measurin customer satisfaction index which is held in advance before the worse situation that might be happened.

Finally, the marketer has to cultivate and increase brand equity performances through the performances of self congruity, brand relationship quality, and brand loyalty. The research findings revealed that the the performances of MANGO self congruity, brand relationship quality, and brand loyalty are still on the middle level. It showed the average performances instead of the excellent performances. According to Kressmann et al (2006) stated that self congruity influences brand relationship quality and brand loyalty. Therefore the marketer has to assure that the brand could achieve the high level of congruity, relationship quality, and loyalty in order to produce excellent brand equity performances. 